\title{
DNA Relatedness of Thermus Strains, Description of Thermus brockianus sp. nov., and Proposal To Reestablish Thermus thermophilus (Oshima and Imahori)
}

\author{
RALPH A. D. WILLIAMS, ${ }^{1 *}$ KELVIN E. SMITH, ${ }^{1}$ SIMON G. WELCH, ${ }^{1}{ }^{J A N I C E ~ M I C A L L E F, ~}$ \\ AND RICHARD J. SHARP ${ }^{2}$ \\ Department of Biochemistry, Queen Mary and Westfield College, London, E1 4NS, ${ }^{1}$ and Division of Biotechnology, Public Health \\ Laboratory Service, Centre for Applied Microbiology and Research, Porton Down, Salisbury, Wiltshire SP4 0JG, ${ }^{2}$ United Kingdom
}

\begin{abstract}
Aerobic, thermophilic, gram-negative bacteria obtained from Yellowstone National Park that were placed in the genus Thermus on the basis of phenotypic data were examined by chemotaxonomic techniques to determine their peptidoglycan compositions, their respiratory quinones, their mean DNA base compositions, and their levels of DNA-DNA homology as determined by both the filter hybridization and reassociation rate methods. These isolates from hot springs included Thermus aquaticus strains and strains of a new genospecies. We propose the name Thermus brockianus for this new genospecies; strain YS38 is the type strain of this taxon. A collection of 10 strains, including the type strain of "Thermus thermophilus," which were isolated from widely separated geothermal sites, exhibited high levels of DNA-DNA homology with each other and had similar physiological properties. Therefore, we propose that the species Thermus thermophilus (Oshima and Imahori) should be reestablished, with strain $\mathrm{HB8}$ as the type strain.
\end{abstract}

The thermophilic genus Thermus and its type species, Thermus aquaticus, were described by Brock and Freeze (3) as nonsporulating, heterotrophic, rod-shaped organisms whose optimum $\mathrm{pH}$ was between 7.0 and 8.0 and whose optimum temperature for aerobic growth was $70^{\circ} \mathrm{C}$. The Gram reaction of these organisms is negative, and the cell walls of Thermus strains have an outer layer that balloons out from the peptidoglycan layer at regular intervals to give a corrugated appearance to the cell surface (47). Thermus strains are usually yellow pigmented because of carotenoids, but colorless and brown strains $(20,35)$ have been isolated from unilluminated sources $(2,31,44)$. Thermus ruber, which contains red carotenoids and grows optimally at $60^{\circ} \mathrm{C}$, has also been validly described $(22$, 23), but this species exhibits low levels of DNA-DNA homology with the yellow-pigmented strains (42) and is easily distinguished from them phenotypically. Thermus filiformis is remarkable for its unusual filamentous habit and is a validly described species (15), but a number of isolates from New Zealand exhibit high levels of DNA-DNA homology with the type strain of $T$. filiformis despite their nonfilamentous morphology (9). Thermus sp. strain $\mathrm{HB}^{\mathrm{T}}$ ( $\mathrm{T}=$ type strain) was isolated in Japan and was originally named "Flavobacterium thermophilum" (28); this organism was validly redescribed as "Thermus thermophilus" (29), but subsequently this name was not included on the Approved Lists of Bacterial Names (43) because of the phenotypic similarity of this organism to $T$. aquaticus (6). Two names for Japanese isolates, "Thermus flavus" (37) and "Thermus caldophilus" (45), have not been validly published. Many Thermus strains have been isolated from thermal areas in the United States (24), Japan (46), Iceland (1, $5,16,19-21,32$ ), Belgium (6), Britain (31), New Zealand (14, 15), Portugal (39), the Czech Republic (34), Kenya (48a), and Thailand (17). Thermostable enzymes, including some of biotechnological importance, have been isolated from Thermus strains, but the majority of Thermus isolates have been described only as strains of the genus $(48,49)$. The only validly described species besides $T$. aquaticus are those with striking

* Corresponding author. Phone: 071-982-6337. Fax: 081-983-0531. visual properties, including the red-pigmented organism $T$. ruber $(22,23)$, the filamentous organism $T$. filiformis (15), and the recently described, unusual, brownish organism Thermus scotoductus (20). A valid taxonomy can be constructed only on the basis of detailed knowledge of large collections of isolates. In this paper we describe DNA-DNA homology data and other properties which support reestablishment of T. thermophilus (Oshima and Imahori) as a valid species, with strain HB8 as the type strain, and a proposal to establish a new species, Thermus brockianus, with YS38 as the type strain.

\section{MATERIALS AND METHODS}

Strains and their culture. The Thermus strains which we used and their sources are listed in Table 1 . Cells were grown at $65^{\circ} \mathrm{C}$ in shake flask cultures in medium containing $0.3 \%$ tryptone, $0.1 \%$ yeast extract (Difco), and Castenholtz mineral salts (35). Cells were harvested by centrifugation at $6,000 \times g$ and were stored at $-20^{\circ} \mathrm{C}$.

Respiratory quinones. Cell pastes were freeze-dried and extracted with a 2:1 mixture of chloroform and methanol in the dark overnight (4). Each extract was filtered and concentrated under reduced pressure, applied as a band to a preparative Keiselgel $60 \mathrm{~F}$ thin-layer chromatography plate, and then developed with $15 \%$ diethyl ether in light petroleum (bp 60 to $80^{\circ} \mathrm{C}$ ). The band at $R_{f} 0.8$ that absorbed UV (254-nm) light, which presumptively corresponded to menaquinones, was dissolved in chloroform, concentrated under a stream of nitrogen, and then applied to a reverse-phase thin-layer plate (type RP18F254; Merck) and developed with acetone. The $R_{f}$ values of extracts of Thermus strains were observed under UV (254-nm) light and compared with the $R_{f}$ values of the menaquinones of Bacillus stearothermophilus and T. aquaticus $\mathrm{YT}^{\mathrm{T}}$. UV absorption spectra of extracts of the preparative plates in iso-octane were recorded at wavelengths between 230 and $350 \mathrm{~nm}$.

Peptidoglycan preparation and analysis. Cells were extracted by the rapid peptidoglycan preparation method (41) and were hydrolyzed with $4 \mathrm{M} \mathrm{HCl}$; the preparations were then separated by thin-layer chromatography on cellulose plates and tested for the presence of ornithine (11) and the absence of diaminopimelic acid (36). The amino acids and amino sugars in some samples were quantitatively analyzed with an LKB model 4000 amino acid analyzer.

DNA purification and mean base compositions. Cells were lysed and DNA was purified as described previously for $T$. ruber (42), except that cesium chloride density gradient centrifugation was performed for $16 \mathrm{~h}$ at $18^{\circ} \mathrm{C}$ in a Sorvall type TV-865 vertical rotor at $45,000 \mathrm{rpm}$ (relative centrifugal force, $177,000 \times g$ ). The mean base composition was determined by thermal denaturation in dilute saline citrate with a Gilford Response spectrophotometer or a Pye-Unicam model 8800 spectrophotometer equipped with a model SPX876 programmed heating accessory. Mean base compositions were calculated with reference to the DNA of Escherichia coli DSM $2840(\mathrm{G}+\mathrm{C}$ content, $52 \mathrm{~mol} \%)$ by using the following 
TABLE 1. Sources of the Thermus isolates used

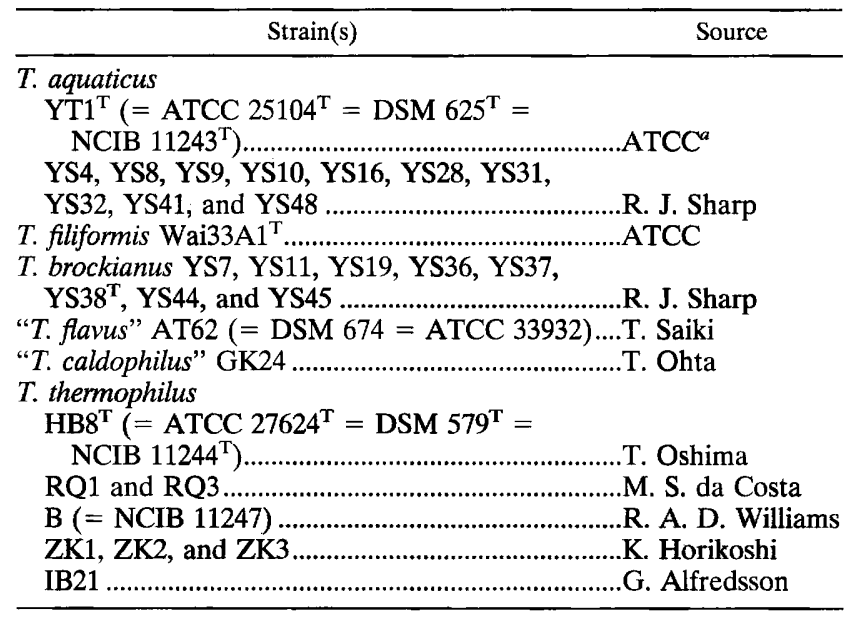

${ }^{a}$ ATCC, American Type Culture Collection.

formula: (30): $\mathrm{G}+\mathrm{C}$ content $=52+2.08\left(T_{m}-T_{m}\right.$ of DSM 2840 DNA), where $T_{m}$ was the thermal denaturation temperature.

DNA-DNA homology. Hybridization of sheared fragments of ${ }^{3} \mathrm{H}$-labeled DNA with single-stranded DNA bound to 5-mm nitrocellulose discs was carried out as described previously (42). Levels of DNA-DNA homology were also determined by measuring the rates of reassociation of pairs of single-stranded sheared DNA samples (7) under optimum conditions with a Gilford Response spectrophotometer. DNA samples in dilute saline citrate were adjusted accurately to an optical density at $260 \mathrm{~nm}$ of 0.70 and sheared by six passages through a 0.625 -in. (ca. $1.59-\mathrm{cm}$ ) 25 -gauge needle under pressure. The fragment size range of each sheared DNA preparation was checked by electrophoresis in $0.3 \%$ agarose gels with TAE buffer (38). DNA samples of each pair of strains, together with a 1:1 mixture of each pair (300- $\mu$ l volumes), were denatured by heating the preparations at $90^{\circ} \mathrm{C}$ in microcuvettes for $10 \mathrm{~min}$. The final sodium concentration used for renaturation $(0.515 \mathrm{M})$ gave an estimated $T_{m}$ of $101^{\circ} \mathrm{C}$ according to the following equation (10): $T_{m}=0.41 \times \mathrm{G}+\mathrm{C}$ content $+78.7+13.3 \log \left[\mathrm{Na}^{+}\right]$. Renaturation temperatures that were 23 and $27^{\circ} \mathrm{C}$ below the $T_{m}$ gave similar homology results. The temperature of the cuvettes was reduced to the renaturation temperature, and $33 \mu \mathrm{l}$ of $5 \mathrm{M}$ sodium chloride at the same temperature was rapidly mixed into each cuvette. The decrease in $A_{260}$ at the renaturation temperature was monitored for $30 \mathrm{~min}$. The rates of reassociation were calculated over the time interval that gave the lowest level of homology with DNAs from T. aquaticus $\mathrm{YT}^{\mathrm{T}}$ and $T$. thermophilus $\mathrm{HB} 8^{\mathrm{T}}$ (from 8 to $18 \mathrm{~min}$ after the renaturation temperature was reached).

\section{RESULTS AND DISCUSSION}

The two instrument systems which we used yielded different $T_{m}$ values for $E$. coli DSM 2840 DNA, but gave the same base compositions for Thermus strains when they were standardized by using the $E$. coli DNA. The mean base compositions of the DNAs of 11 strains of $T$. aquaticus, 8 strains of T. brockianus, and 10 strains of $T$. thermophilus were 61 to 64,61 to 63 , and 63 to $65 \mathrm{~mol} \%$, respectively, values which are consistent with the values obtained for other strains of the genus Thermus.

The respiratory quinones were menaquinones, as judged by their $R_{f}$ values on the preparative thin-layer plates and by their UV absorption spectra. The $R_{f}$ values of the menaquinones of the following strains on the reverse-phase plate were identical to the $R_{f}$ value of the menaquinone of strain $\mathrm{YT}^{\mathrm{T}}$ (menaquinone 8): T. aquaticus YS31, T. brockianus YS38 ${ }^{\mathrm{T}}$, YS44, and YS45, T. thermophilus $\mathrm{HB} 8^{\mathrm{T}}, \mathrm{B}, \mathrm{ZK} 3$, and IB21, and $T$. filiformis Wai33A1 ${ }^{\mathrm{T}}$.

Our qualitative analysis confirmed that ornithine was the major dibasic amino acid in the peptidoglycan of all strains and that lysine occurred as a minor substituent (33). This characteristic distinguishes Thermus strains, which have peptidoglycan cross-linked by ornithine, from the thermophilic bacilli, which are sometimes yellowish when they are first isolated and do not always sporulate freely, but for the most part have peptidoglycans containing diaminopimelic acid. The molar ratios of amino compounds to ornithine were as follows: glutamate, 1.52 to 2.35 ; glycine, 2.85 to 3.40 ; alanine, 2.02 to 3.50 ; and glucosamine, 0.58 to 1.20 . These values agree with values obtained in previous analyses of Thermus strains. The rather high glutamate content and the presence of other amino acids indicate that the peptidoglycan was not free of protein.

The strains identified as members of the genospecies $T$. thermophilus exhibited high levels of intragroup DNA-DNA homology (Table 2), but low levels of homology with strains of both $T$. aquaticus and $T$. filiformis, as well as with strains belonging to the new genospecies described below as $T$. brockianus (Table 3). The T. thermophilus homology cluster includes the Japanese isolates of $T$. thermophilus, "T. flavus," and " $T$. caldophilus," as well as the more recently isolated organisms strains ZK1, ZK2, and ZK3 from Japan (46), strains RQ1 and RQ3 from Portugal (39), strain B from a terrestrial source in Iceland (47), and strain IB21 from a submarine hot spring (21) off the coast of Iceland. This species is distributed widely in hot springs.

The results of molecular biology studies, including the catalog of oligonucleotides derived from hydrolysis of $16 \mathrm{~S}$ rRNA (27), indicated that there is a distinct, if remote, relationship between the genus Thermus (represented by $T$. aquaticus and T. ruber) and the genus Deinococcus (13). Alignment of the $16 \mathrm{~S}$ RNA gene of $T$. thermophilus $\mathrm{HB}^{\mathrm{T}}(12,25)$ with other $16 \mathrm{~S}$ RNA sequences led to the conclusion that $T$. thermophilus is a green nonsulfur bacterium, along with Thermomicrobium roseum, Chloroflexus aurantiacus, and Herpetosiphon aurantiacus. This is the second deepest bacterial branchpoint after Thermotoga maritima. Many more 16S rRNA and 16S ribosomal DNA (rDNA) sequences are now available for Thermus strains (25, 26,40 ). The sequences of the genes for the 16S rRNAs of $T$. ruber, T. brockianus YS38 ${ }^{\mathrm{T}}$, and strains Vi7 and SPS14 (8) confirmed that the yellow-pigmented Thermus strains are closely related to each other, but not to $T$. ruber. The lower "thermophilic bias" evident in the sequence of the $T$. ruber gene, which is associated with the lower growth temperature of this organism compared with the yellow strains, was important in confirming the relationship between the thermophilic genus Thermus and the mesophilic genus Deinococcus (8).

The sequences of the $16 \mathrm{~S}$ rDNAs of $T$. aquaticus $\mathrm{YT}^{\mathrm{T}}$, " $T$. flavus" AT62, Thermus sp. strains HSA1, OK6A1, Rt41A, T351, Tok8A1, Tok20A1, ZHGIA1, and T. filiformis Wai33A $1^{\mathrm{T}}$, and $T$. ruber were determined by Saul et al. (40) and deposited in the GenBank database. When these sequences were aligned with those of $T$. aquaticus YS25 and YS52 (sequences determined at the Deutsche Sammlung von Mikroorganismen und Zellkulturen for R. J. Sharp [unpublished data]), T. thermophilus $\mathrm{HB}^{\mathrm{T}}(12,25)$, T. thermophilus HB27 (40), and T. brockianus YS38 ${ }^{\mathrm{T}}(8)$, a region including helix 10 (Table 4) was found to be species specific. The sequence of strain HSA1 (isolated on the South Island of New Zealand [15]) is very similar to that of T. thermophilus $\mathrm{HB}^{\mathrm{T}}$; there are only 13 differences between the two sequences. The status of "T. flavus," which was identified as a member of the genospecies $T$. thermophilus by DNA-DNA homology (Table 2 ), was confirmed by the $16 \mathrm{~S}$ rDNA sequence of this organism, which differed from the sequence of $T$. thermophilus $\mathrm{HB}^{\mathrm{T}}$ (12) at only six positions. Strain HB27, a strain that is frequently used as a host for cloning in the genus Thermus (18), was confirmed as a member of $T$. thermophilus because the $16 \mathrm{~S}$ rDNA sequence of this strain is identical to that of " $T$. flavus." Therefore, $T$. thermophilus seems to be a valid species that is widely distributed in thermal areas around the world. 
TABLE 2. Levels of DNA-DNA homology for T. aquaticus, T. brockianus, $T$. thermophilus, and $T$. filiformis strains as determined by the filter method

\begin{tabular}{|c|c|c|c|c|c|c|c|c|c|c|c|c|c|c|c|c|c|c|c|}
\hline \multirow{3}{*}{ Strain on filter } & \multicolumn{19}{|c|}{ \% Homology with: } \\
\hline & \multicolumn{5}{|c|}{ T. aquaticus strains } & \multicolumn{6}{|c|}{ T. brockianus strains } & \multicolumn{7}{|c|}{ T. thermophilus strains } & \multirow{2}{*}{$\begin{array}{l}\text { T. filiformi } \\
{\text { Wai33A } 1^{\mathrm{T}}}^{\mathrm{T}}\end{array}$} \\
\hline & $\overline{\mathrm{YT} 1^{\mathrm{T}}}$ & YS4 & YS10 & YS31 & YS48 & $\overline{\text { YS7 }}$ & YS11 & YS36 & YS37 & YS $38^{\mathrm{T}}$ & $\overline{\text { YS44 }}$ & $\overline{\text { HB8 }^{T}}$ & GK24 & AT62 & $\mathrm{B}$ & ZK1 & IB21 & $\overline{\mathrm{RQ1}}$ & \\
\hline \multicolumn{20}{|l|}{ T. aquaticus } \\
\hline $\mathrm{YT}^{\mathrm{T}}$ & 100 & 92 & 78 & 94 & 94 & 35 & 34 & 49 & 47 & 42 & 43 & 44 & 52 & 52 & 42 & 50 & 39 & 48 & 37 \\
\hline YS4 & 77 & 100 & 76 & 69 & 68 & 28 & 29 & 36 & 31 & 34 & 33 & 43 & 32 & 29 & 33 & 38 & 41 & 32 & 45 \\
\hline YS8 & 98 & & 77 & 92 & 90 & 30 & 29 & 45 & 30 & 36 & 38 & 37 & 34 & 26 & 32 & 50 & 35 & 27 & 30 \\
\hline YS9 & 84 & 85 & 97 & 100 & 97 & 36 & 32 & 50 & & 42 & 48 & 49 & 49 & 54 & 45 & 49 & 36 & 29 & 27 \\
\hline YS10 & 84 & & 100 & 85 & 98 & 42 & 32 & 47 & 27 & 49 & 44 & 36 & 26 & 26 & 36 & 51 & 44 & 28 & 29 \\
\hline YS16 & 82 & 78 & & 88 & & & & 34 & 27 & & & 43 & 35 & 38 & 38 & & & & 38 \\
\hline YS28 & 74 & 78 & 79 & 89 & 86 & 37 & & 47 & 35 & 36 & 42 & 38 & 34 & 50 & 41 & & & & \\
\hline YS31 & & 76 & 79 & 100 & 80 & & & 43 & 31 & & 38 & 44 & 43 & 47 & 37 & & & & \\
\hline YS32 & 76 & 82 & 78 & 90 & 70 & 33 & 42 & 27 & 32 & 31 & 35 & 35 & 31 & 33 & 40 & 40 & 39 & 36 & 32 \\
\hline YS41 & 81 & & 75 & 84 & 69 & 28 & & 40 & & 29 & 30 & 32 & 31 & 43 & 37 & & & & \\
\hline YS48 & & & 90 & 82 & 100 & 29 & 35 & 35 & 28 & 24 & 28 & 37 & 37 & & & 33 & 39 & 29 & 29 \\
\hline \multicolumn{20}{|l|}{ T. brockianus } \\
\hline YS11 & & 49 & & 43 & & & 100 & 86 & 78 & 80 & & 46 & 35 & 37 & 25 & 28 & 28 & 29 & 30 \\
\hline YS19 & 50 & 49 & 40 & 45 & 32 & 69 & & 79 & 77 & 83 & 85 & 41 & 52 & 51 & 33 & & & & \\
\hline YS36 & 46 & 42 & 35 & 43 & 57 & 100 & 86 & 100 & & 77 & 78 & 27 & 35 & 37 & 40 & 29 & 38 & 29 & 29 \\
\hline YS37 & 40 & 40 & 38 & 30 & & & 100 & 100 & 100 & & & 41 & 28 & 37 & 31 & 32 & 38 & 34 & 39 \\
\hline $\mathrm{YS} 38^{\mathrm{T}}$ & 48 & 35 & 49 & 34 & 54 & 98 & 90 & 95 & 86 & 100 & 90 & 30 & 25 & 25 & 31 & 43 & 39 & 39 & 38 \\
\hline YS44 & 44 & & 50 & 54 & 34 & 92 & 103 & 100 & & 92 & 100 & 37 & 35 & 40 & 35 & 50 & & & 35 \\
\hline YS45 & 40 & & 32 & 48 & 21 & 78 & & 86 & 78 & 88 & 73 & 31 & 41 & 40 & 35 & 46 & 36 & 33 & 33 \\
\hline \multicolumn{20}{|l|}{ T. thermophilus } \\
\hline $\mathrm{HB}^{\mathrm{T}}$ & 38 & 42 & 38 & 43 & 35 & 28 & 29 & 31 & 40 & 28 & 28 & 100 & 82 & 88 & 86 & 82 & 76 & 87 & 37 \\
\hline GK24 & 35 & 46 & & 29 & & & & 36 & 32 & 36 & & 88 & 100 & 90 & 81 & & & & \\
\hline AT62 & 33 & 50 & & 38 & & & & 36 & 30 & 30 & & 82 & 100 & 100 & 78 & & & & \\
\hline B & 30 & 32 & & 40 & & & & 33 & 27 & 29 & & 89 & 84 & 88 & 100 & 85 & 79 & 81 & 41 \\
\hline ZK1 & 41 & 38 & & 38 & & & 29 & & & 28 & & 100 & 88 & & & 100 & 77 & 86 & 39 \\
\hline $\mathrm{ZK} 2$ & 35 & 39 & & 39 & & & 42 & & & 35 & & 100 & 94 & & & 97 & 78 & 81 & 37 \\
\hline$\overline{\mathrm{ZK} 3}$ & 35 & 41 & & 41 & & & 33 & & & 42 & & 94 & 99 & & & 93 & 78 & 79 & 30 \\
\hline IB21 & 34 & 35 & & 35 & & & 29 & & & 33 & & 78 & 87 & & & 83 & 100 & 85 & 32 \\
\hline RQ1 & 38 & & & 37 & & & 39 & & & 42 & & 99 & 86 & & & 88 & 82 & 100 & 29 \\
\hline
\end{tabular}

A total of 48 Thermus isolates obtained from several hot springs in Yellowstone National Park were examined by using 71 phenetic characteristics (24), and two major clusters were distinguished at a level of similarity of $80 \%$. Cluster 1 represented $T$. aquaticus, although type strain YT1 clustered at a similarity level of only $83 \%$ with the rest of the group. Subcluster $1 \mathrm{~b}$, which contained four isolates, was distinguished from the other organisms by its lack of proteolytic activity and anaerobic growth on nitrate (24). Strains in cluster 1 belong to the $T$. aquaticus DNA-DNA homology group (Table 2). The group 2 strains were typified by a pale spreading colony morphology on agar plates in the phenotypic study (24). This group also included several reference strains, including $T$. thermophilus $\mathrm{HB}^{\mathrm{T}}$ and B and "T. caldophilus" and "T. flavus" strains.

TABLE 3. Levels of DNA-DNA homology for T. aquaticus, $T$. filiformis, $T$. thermophilus, and $T$. brockianus strains as determined by the spectrophotometric method

\begin{tabular}{|c|c|c|c|c|c|c|c|c|c|c|}
\hline \multirow{2}{*}{ Strain } & \multicolumn{10}{|c|}{$\%$ Homology with strain: } \\
\hline & $\overline{\mathrm{YT} 11^{\mathrm{T}}}$ & YS31 & Wai33A1 ${ }^{\mathrm{T}}$ & $\mathrm{HB}^{\mathrm{T}}$ & YS11 & YS19 & YS36 & $\mathrm{YS} 8^{\mathrm{T}}$ & YS44 & YS45 \\
\hline \multicolumn{11}{|l|}{ T. aquaticus } \\
\hline $\mathrm{YT}^{\mathrm{T}}$ & 100 & 98 & 35 & 43 & & 39 & & 42 & & 41 \\
\hline YS31 & & 100 & & & 32 & 42 & 28 & 31 & 37 & 47 \\
\hline T. filiformis Wai33A1 ${ }^{\mathrm{T}}$ & & & 100 & 36 & & & & 21 & & \\
\hline T. thermophilus $\mathrm{HB} 8^{\mathrm{T}}$ & & & & 100 & & & & 36 & & \\
\hline $\begin{array}{l}\text { T. brockianus } \\
\text { YS11 }\end{array}$ & & & & & 100 & 100 & 91 & & 100 & 87 \\
\hline YS19 & & & & & & 100 & & 89 & 75 & 82 \\
\hline YS36 & & & & & & & 100 & & 93 & 100 \\
\hline $\mathrm{YS}^{2} 8^{\mathrm{T}}$ & & & & & & & & 100 & & 89 \\
\hline YS44 & & & & & & & & & 100 & 75 \\
\hline
\end{tabular}


TABLE 4. Sequences of the 16S rDNAs of $T$. aquaticus, $T$. thermophilus, $T$. filiformis, and $T$. brockianus strains in the species-specific regions of helices 6 and 10

\begin{tabular}{|c|c|c|}
\hline \multirow{2}{*}{ Strain or taxon } & \multicolumn{2}{|c|}{ Sequence in the species-specific region of ${ }^{a}$ : } \\
\hline & Helix $6^{b}$ & Helix $10^{c}$ \\
\hline \multicolumn{3}{|l|}{ T. aquaticus } \\
\hline $\mathrm{YT}^{\mathrm{T}}$ & CGTgggg---taTCTCACg & ACACATCCTGTggggTGTgTTTaaagggTTTTGCC \\
\hline YS25 & CGTgggg---taTCTCACg & ACACATCCTGTggggTGTgTTTaaagggTTTTGCC \\
\hline YS52 & CGTgggg---taTCTCACg & ACACATCCTGTggggTGTgTTTaaagggTTTTGCC \\
\hline \multicolumn{3}{|l|}{ T. thermophilus } \\
\hline $\mathrm{HB}^{\mathrm{T}}$ & CGCggggTTTtaCTCCGTg & ACCCGCCCCTTggggTGTgTCCaaagggCTTTGCC \\
\hline HB27 & CGCggggTTTtaCTCCGTg & ACCCGCCCCTTggggTGTgTCCaaagggCTTTGCC \\
\hline "T. flavus" & CGCggggTTTtaCTCCGTg & ACCCGCCCCTTggggTGTgTCCaaagggCTTTGCC \\
\hline HSA1 & CGCggggTTTtaCTCTGCg & GCCCGCCCCTTggggCGTgTCCaaagggCTTTGCC \\
\hline & ** & * \\
\hline \multicolumn{3}{|l|}{ T. filiformis } \\
\hline Wai33A1 $^{\mathrm{T}}$ & TGCggggTTTtaCTCCGTg & TCGTGCCCTTTggggTGCgATTaaagggTGAAGAG \\
\hline Tok20A1 & CGCggggTTTtaCTTCGCg & TCGTGCCCTTTggggTGCgATTaaagggTGAAGAG \\
\hline OK6A1 & TGCggggTTTtaCTTCGCg & TCGTGCCCTTTggggTGCgATTaaagggTGAAGAG \\
\hline RT41A & TGCggggTTTtaCTTCGCg & TCGTGCCCTTTggggTGCgATTaaagggTGAAGAG \\
\hline T351 & TGCggggTTTtaCTTCGCg & TCGTGCCCTTTggggTGCgATTaaagggTGAAGAG \\
\hline \multirow[t]{2}{*}{ Tok8A1 } & CGCggggTTTtaCTTCGCg & TCGTGCCCTTTgggg'TGCgATTaaagggTGAAGAG \\
\hline & * $\quad$ * & \\
\hline \multicolumn{3}{|l|}{ T. brockianus } \\
\hline $\mathrm{YS}^{2} 8^{\mathrm{T}}$ & CATggggTTTtaCTCCGTg & TCATGTCCTGTggggCATgATTaaagggCGAGAGT \\
\hline ZHGIA1 & CATggggTTTtaCTCCGTg & TCATGTCCTGTggggCATgATTaaagggCGAGAGT \\
\hline
\end{tabular}

The levels of DNA homology reported in Tables 2 and 3 show that the cluster 2 Yellowstone isolates form a DNA homology group that is distinct from both $T$. aquaticus and T. thermophilus. We propose that this group should be called Thermus brockianus in honor of T. D. Brock.

There is only one difference between the 16S rDNA sequence of $T$. brockianus $\mathrm{YS}^{\mathrm{T}}{ }^{\mathrm{T}}$ from North America and the $16 S$ rDNA sequence of strain ZHG1A1 from Iceland $(16,40)$. This indicates that strain ZHG1A1 is a $T$. brockianus strain, and this is further evidence that the geographic spread of Thermus species is wider than has often been thought. A description of $T$. brockianus sp. nov. is given below.
Thermus brockianus sp. nov. Thermus brockianus (brock i.a.nus. N.L. adj. brockianus, referring to T. D. Brock, who initiated a new era of thermophile microbiology and described the genus Thermus on the basis of isolates obtained from Yellowstone National Park). Aerobic, heterotrophic, thermophilic, short rods that are gram negative. Paler yellow pigmentation than $T$. aquaticus. Distinctive spreading colonial morphology occurs on tryptone-yeast extract plates at $70^{\circ} \mathrm{C}$. The peptidoglycan has ornithine cross-links with glycine in the interpeptide bridge. The respiratory quinone is menaquinone 8. The $\mathrm{G}+\mathrm{C}$ content of the DNA is 61 to $63 \mathrm{~mol} \%$. Most strains grow on fructose, galactose, and trehalose, but only a

TABLE 5. Phenotypic characteristics that distinguish type strains and clusters of Thermus strains

\begin{tabular}{|c|c|c|c|c|c|c|c|c|c|}
\hline \multirow{2}{*}{ Taxon or group } & \multirow{2}{*}{$\begin{array}{l}\text { Pale spreading } \\
\text { colonies }\end{array}$} & \multicolumn{5}{|c|}{ Growth $^{a}$ on: } & \multicolumn{3}{|c|}{ Hydrolysis $^{a}$ of: } \\
\hline & & Glucose & Fructose & Galactose & Mannose & Trehalose & Casein & Gelatin & Starch \\
\hline \multicolumn{10}{|l|}{ T. aquaticus } \\
\hline $\mathrm{YT} 1^{\mathrm{T}}$ & - & - & - & - & + & - & + & + & + \\
\hline 11 strains $^{b}$ & 0 & 18 & 9 & 18 & 27 & 27 & 64 & 64 & 55 \\
\hline 29 strains $^{c}$ & 0 & 17 & 10 & 48 & 31 & 35 & 90 & 83 & 83 \\
\hline \multicolumn{10}{|l|}{ T. brockianus } \\
\hline$Y^{\prime} 38^{T}$ & + & - & + & + & - & + & - & - & - \\
\hline 8 strains $^{b}$ & 87 & 25 & 87 & 63 & 25 & 75 & 0 & 25 & 25 \\
\hline 13 strains $^{c}$ & 92 & 23 & 85 & 69 & 38 & 77 & 0 & 15 & 46 \\
\hline \multicolumn{10}{|l|}{ T. thermophilus } \\
\hline $\mathrm{HB}^{\mathrm{T}}{ }^{\mathrm{T}}$ & + & + & + & + & - & + & - & - & - \\
\hline 3 strains $^{d}$ & 0 & 100 & 100 & 100 & 100 & 33 & 0 & 0 & 0 \\
\hline
\end{tabular}

${ }^{a}-$, negative; +, positive. The numbers are the percentages of positive strains for each group (see below).

${ }^{b}$ Strains used in DNA-DNA homology tests.

${ }^{c}$ Strains used in phenotypic tests (21).

${ }^{d}$ Strains $\mathrm{HB8}^{\mathrm{T}}, \mathrm{B}$, and AT62. 
minority of the strains grow on glucose or mannose. None of the strains hydrolyzes casein in plate assays, although a minority hydrolyze clear gelatin and starch. The type strain is strain YS38, which was isolated by R. J. Sharp from Pine Spring in Yellowstone National Park (24). Phenotypic characteristics which distinguish $T$. brockianus from $T$. aquaticus and $T$. thermophilus are shown in Table 5.

\section{ACKNOWLEDGMENTS}

Some of the DNAs were prepared during a 2-month visit to the Komagome laboratory of K. Horikoshi under the Japan Research Development Corporation "Superbugs" Project. The hospitality of K Horikoshi and the helpful discussions with his staff and with Tairo Oshima are gratefully acknowledged.

\section{REFERENCES}

1. Alfredsson, G. A., S. Baldursson, and J. K. Kristjansson. 1985. Nutritional diversity among Thermus spp. isolated from Icelandic hot springs. Syst. Appl. Microbiol. 6:308-311.

2. Brock, T. D., and K. L. Boylen. 1973. Presence of thermophilic bacteria in laundry and domestic hot-water heaters. Appl. Microbiol. 25:72-76.

3. Brock, T. D., and H. Freeze. 1969. Thermus aquaticus gen. n. and sp. n., a nonsporulating extreme thermophile. J. Bacteriol. 98:289-297.

4. Collins, M. D., and D. Jones. 1981. Distribution of isoprene quinone structural types in bacteria and their taxonomic implications. Microbiol. Rev. 45:316-354.

5. Cometta, S., B. Sonnleitner, W. Sidler, and A. Fiechter. 1982. Population distribution of aerobic extremely thermophilic microorganisms in an Icelandic natural hot spring. Eur. J. Appl. Microbiol. Biotechnol. 16:151-156.

6. Degryse, E., N. Glansdorfi, and A. Pierard. 1978. A comparative analysis of extreme thermophilic bacteria belonging to the genus Thermus. Arch. Microbiol. 117:189-196

7. De Ley, J., H. Cattoir, and A. Reynaerts. 1970. The quantitative measurement of DNA hybridisation from renaturation rates. Eur. J. Biochem. 12. 133-142.

8. Embley, T. M., R. H. Thomas, and R. A. D. Williams. 1993. Reduced thermophilic bias in the 16S rDNA sequence from Thermus ruber provides further support for a relationship between Thermus and Deinococcus. Syst. Appl. Microbiol. 16:25-29.

9. Georganta, G., K. E. Smith, and R. A. D. Williams. 1993. DNA:DNA homology and cellular components of Thermus filiformis and other strains of Thermus from New Zealand hot springs. FEMS Microbiol. Lett. 107:145150.

10. Gillis, M., J. De Ley, and M. De Cleene. 1970. The determination of molecular weight of bacterial genome DNA from renaturation rates. Eur. J. Biochem. 12:143-153.

11. Hardy, T. L., D. O. Holland, and J. H. C. Nayler. 1955. One-phase solvent systems for the separation of amino acids. Anal. Chem. 27:971-973.

12. Hartmann, R. K., J. Wolters, B. Kroger, S. Schultze, T. Specht, and V. A Erdmann. 1989. Does Thermus represent another deep eubacterial branching? Syst. Appl. Microbiol. 11:243-249.

13. Hensel, R., W. Demharter, O. Kandler, R. M. Kroppenstedt, and E. Stackebrandt. 1986. Chemotaxonomic and molecular-genetic studies of the genus Thermus: evidence for a phylogenetic relationship of Thermus aquaticus and Thermus ruber to the genus Deinococcus. Int. J. Syst. Bacteriol. 36:444-453.

14. Hudson, J. A., H. W. Morgan, and R. M. Daniel. 1986. A numerical classification of some Thermus isolates. J. Gen. Microbiol. 132:531-540.

15. Hudson, J. A., H. W. Morgan, and R. M. Daniel. 1987. Thermus filiformis sp. nov., a filamentous caldoactive bacterium. Int. J. Syst. Bacteriol. 37:431-436.

16. Hudson, J. A., H. W. Morgan, and R. M. Daniel. 1987. Numerical classification of some Thermus isolates from Icelandic hot springs. Syst. Appl Microbiol. 9:218-223.

17. Kanasawud, P., S. Teeyapan, S. Lumyong, O. Holst, and B. Mattiasson. 1992. Thermus 2S from Thai hot springs: isolation and immobilization. World J. Microbiol. Biotechnol. 8:137-140.

18. Koyama, Y., and K. Furukawa. 1990. Cloning and sequence analysis of tryptophan synthetase genes of an extreme thermophile, Thermus thermophilus HB27: plasmid transfer from replica-plated Escherichia coli recombinant colonies to competent $T$. thermophilus cells. J. Bacteriol. 172:3490-3495.

19. Kristjansson, J. K., and G. A. Alfredsson. 1983. Distribution of Thermus spp in Icelandic hot springs and a thermal gradient. Appl. Environ. Microbiol. 45:1785-1789.

20. Kristjansson, J. K., S. Hjorleifsdottir, V. T. Marteinsson, and G. A. Alfredsson. 1994. Thermus scotoductus, sp. nov., a pigment-producing thermophilic bacterium from hot tap water in Iceland and including Thermus sp. X1. Syst. Appl. Microbiol. 17:44-50.
21. Kristjansson, J. K., G. O. Hreggvidsson, and G. A. Alfredsson. 1986. Isolation of halotolerant Thermus spp. from submarine hot springs in Iceland. Appl. Environ. Microbiol. 52:1313-1316.

22. Loginova, L. G., and L. A. Egorova. 1976. An obligately thermophilic bacterium Thermus ruber from hot springs in Kamchatka. Microbiology (Engl Transl. Mikrobiologiya) 44:593-597.

23. Loginova, L. G., L. A. Egorova, R. S. Golovacheva, and L. M. Seregina. 1986. Thermus ruber sp. nov. Int. J. Syst. Bacteriol. 34:498-499.

24. Munster, M. J., A. P. Munster, J. R. Woodrow, and R. J. Sharp. 1986 Isolation and preliminary taxonomic studies of Thermus strains isolated from Yellowstone National Park, USA. J. Gen. Microbiol. 132:1677-1683.

25. Murzina, N. V., D. P. Vorozheykina, and N. I. Matvienko. 1988. Nucleotide sequence of Thermus thermophilus HB8 gene coding 16S rRNA. Nucleic Acids Res. 16:8172.

26. Neefs, J.-M., Y. Van de Peer, P. De Rijk, A. Goris, and R. De Wachter. 1991 Compilation of small ribosomal subunit RNA sequences. Nucleic Acids Res. 19(Suppl.):1987-2015.

27. Olsen, G. J., N. Larsen, and C. R. Woese. 1991. The Ribosomal RNA Database Project. Nucleic Acids Res. 19(Suppl.):2017-2021.

28. Oshima, T., and K. Imahori. 1971. Isolation of an extreme thermophile and thermostability of its transfer ribonucleic acid and ribosomes. J. Gen. Appl. Microbiol. 17:513-517.

29. Oshima, T., and K. Imahori. 1974. Description of Thermus thermophilus (Yoshida and Oshima) comb. nov., a nonsporulating thermophilic bacterium from a Japanese thermal spa. Int. J. Syst. Bacteriol. 24:102-112.

30. Owen, R. J., and L. R. Hill. 1979. The estimation of base composition, base pairing and genome sizes of bacterial DNA. Soc. Appl. Bacteriol. Tech. Ser 14:277-296.

31. Pask-Hughes, R., and R. A. D. Williams. 1975. Extremely thermophilic gram-negative bacteria from hot tap water. J. Gen. Microbiol. 88:321-328.

32. Pask-Hughes, R. A., and R. A. D. Williams. 1977. Yellow-pigmented strains of Thermus spp. from Icelandic hot springs. J. Gen. Microbiol. 102:375-383.

33. Pask-Hughes, R. A., and R. A. D. Williams. 1978. Cell envelope components of strains belonging to the genus Thermus. J. Gen. Microbiol. 107:65-72.

34. Peckova, M. 1991. Properties of a hyperthermophilic bacterium (Thermus sp.) isolated from a Carlsbad spring. Folia Microbiol. 36:515-521.

35. Ramaley, R. F., and J. Hixson. 1970. Isolation of a nonpigmented, thermophilic bacterium similar to Thermus aquaticus. J. Bacteriol. 103:527-528.

36. Rhuland, L. E., E. Work, R. F. Denman, and D. S. Hoare. 1955. The behaviour of isomers of $\alpha$ - $\varepsilon$-diaminopimelic acid on paper chromatograms. J. Am. Chem. Soc. 77:4844-4846.

37. Saiki, T., R. Kimura, and K. Arima. 1972. Isolation and characterization of extremely thermophilic bacteria from hot springs. Agric. Biol. Chem. 36 2357-2366.

38. Sambrook, J., E. F. Fritsch, and T. Maniatis. 1989. Molecular cloning: a laboratory manual, 2nd ed. Cold Spring Harbor Laboratory Press, Cold Spring Harbor, N.Y.

39. Santos, M. A., R. A. D. Williams, and M. S. da Costa. 1990. Numerical taxonomy of Thermus isolates from hot springs in Portugal. Syst. Appl. Microbiol. 12:310-315.

40. Saul, D. J., A. G. Rodrigo, R. A. Reeves, L. C. Williams, K. M. Borges, H. W. Morgan, and P. L. Bergquist. 1993. Phylogeny of twenty Thermus isolates constructed from 16S rRNA gene sequence data. Int. J. Syst. Bacteriol. 43:754-760.

41. Schleifer, K. H., and O. Kandler. 1972. Peptidoglycan types of bacterial cell walls and their taxonomic implications. Bacteriol. Rev. 36:245-292.

42. Sharp, R. J., and R. A. D. Williams. 1988. Properties of Thermus ruber strains isolated from Icelandic hot springs and DNA-DNA homology of Thermus ruber and Thermus aquaticus. Appl. Environ. Microbiol. 54:2049-2053.

43. Skerman, V. B. D., V. McGowan, and P. H. A. Sneath (ed.). 1980. Approved lists of bacterial names. Int. J. Syst. Bacteriol. 30:225-420.

44. Stramer, S. L., and M. J. Starzyk. 1981. The occurrence and survival of Thermus aquaticus. Microbios 32:99-110.

45. Taguchi, H., M. Yamashita, H. Matsuzawa, and T. Ohta. 1982. Heat stable and fructose 1,6-biphosphate activated L-lactate dehydrogenase from an extremely thermophilic bacterium. J. Biochem. 91:1343-1348.

46. Takase, M., and K. Horikoshi. 1989. Purification and properties of a $\beta$-glucosidase from Thermus sp. Z-1. Agric. Biol. Chem. 53:559-560.

47. Williams, R. A. D. 1975 . Caldoactive and thermophilic bacteria and their thermostable proteins. Sci. Prog. 62:373-393.

48. Williams, R. A. D. 1989. Biochemical taxonomy of the genus Thermus, p. 82-97. In M. S. da Costa, J. C. Duarte, and R. A. D. Williams (ed.) Microbiology of extreme environments and its potential for biotechnology. Elsevier, London.

48a.Williams, R. A. D. Unpublished data.

49. Williams, R. A. D., and M. S. da Costa. 1992. The genus Thermus and related microorganisms, p. 3745-3753. In A. Balows, H. G. Trüper, M. Dworkin, W. Harder, and K.-H. Schleifer (ed.), The prokaryotes. A handbook on the biology of bacteria: ecophysiology, isolation, identification, applications. Springer-Verlag, New York. 